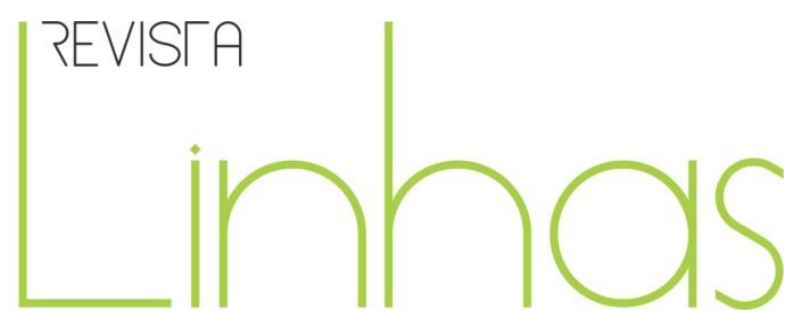

\title{
A escola primária no Rio Grande do Sul através das fotografias: espaços, sujeitos e cultura material (1924) 1
}

\begin{abstract}
Resumo
O estudo analisa um conjunto de 20 fotografias publicadas como anexo do Relatório da Diretoria de Instrução Pública do Estado do Rio Grande do Sul, em 1924. Propõe discutir como a fotografia constitui um fragmento para a investigação sobre a história da educação, representando formas escolares, discursos políticos, médicos e pedagógicos, que participaram da construção da Primeira República Brasileira (1889-1930). Identificamos a presença de 12 instituições, englobando colégios elementares, grupos escolares e escolas isoladas de sete municípios do Estado. Constatamos que a maioria das fotografias destaca o edifício escolar, presente nos discursos como fator de melhoria da qualidade da educação. Visualizamos também a presença do diretor, de professoras e alunos/as, representando visualmente uma nova organização escolar introduzida pelos princípios da escola graduada, com a incorporação novos sujeitos e agrupamento de docentes e alunos, de diferentes níveis de ensino, em um mesmo espaço escolar.
\end{abstract}

Palavras-chave: Escola Primária. Fotografias. Primeira República. Arquitetura Escolar

\author{
Tatiane de Freitas Ermel \\ Universidade Regional Integrada \\ do Alto Uruguai e das Missões - \\ Frederico Westphalen - \\ Brasil \\ tatiane.ermel@acad.pucrs.br
}

\footnotetext{
Para citar este artigo:

ERMEL, Tatiane de Freitas A escola primária no Rio Grande do Sul através das fotografias: espaços, sujeitos e cultura material (1924). Revista Linhas. Florianópolis, v. 19, n. 40, p. 331-359, maio/ago. 2018.
}

DOI: $10.5965 / 1984723819402018331$

http://dx.doi.org/10.5965/1984723819402018331

\footnotetext{
${ }^{1}$ Uma versão preliminar e reduzida deste estudo foi apresentada no XVIII Coloquio de Historia de la Educación: Arte, Literatura y Educación. Universitat de Vic - Universitat Central de Catalunya, em julho de 2015.

* O presente trabalho foi realizado com apoio do CNPq, Conselho Nacional de Desenvolvimento Científico e Tecnológico/Brasil ( $n^{\circ}$ do processo: 150430/2017-8).
} 


\title{
The primary school in Rio Grande do Sul through photographs: spaces, subjects and material culture (1924)
}

\begin{abstract}
The Study analyzes a set of 20 photographs published as an appendix to Public Instruction Management Report of the State of Rio Grande do Sul in 1924. It discusses how the photograph is a fragment for research in history of education, representing forms and school practices, political, medical and educational speeches, that participated in the construction of the First Brazilian Republic (1889-1930). We have identified the presence of 12 institutions, including elementary schools, school groups and isolated schools in seven municipalities from the Estate. It was verified that most photos highlights the school building, presents in the speeches as improvement factor of education quality. We also note the presence of the principal, teachers and students visually representing a new school organization introduced by the principles of the graduate school with the incorporation of new subjects and grouping of teachers and students of different levels of education in the same school space.
\end{abstract}

Keywords: Elementary School. Photographs. First Republic. School Architecture. 
A escrita da história partilha das aventuras da composição em imagens da lembrança sob a égide da função ostensiva da imaginação.

(RICOEUR, 2007, p. 70)

Representando discursos políticos, médicos e pedagógicos que participaram da construção da Primeira República Brasileira (1889-1930), a escola primária constituía um espaço de regeneração das esferas estruturais, morais, sociais, biológicas e psicológicas. A instituição escolar, neste período, era vislumbrada como possuidora de todas as forças necessárias para a formação do novo homem, o cidadão republicano. Uma formação que garantisse sanidade mental, higiênica e moral para o convívio social, em que higiene e saúde, vícios e comportamentos, deveriam se alinhar para o progresso da sociedade. A sua configuração em um prédio próprio, ou seja, separado das demais instituições, dotoua de uma identidade particular. As construções monumentais, em diferentes cidades, foram um significativo empreendimento visual de propaganda do regime político republicano, instaurado no Brasil em $1889^{2}$.

A situação precária da educação nacional, no início da República, provocou o acirramento das discussões em torno da necessidade quantitativa e qualitativa de instituições de ensino. Caberia a cada Estado organizar, implementar e fiscalizar a instrução primária, o que já estava previsto desde o Ato Adicional, de $1834^{3}$. Com a República e a Constituição de 1891, a autonomia estadual se concretizou de uma maneira mais ampla, dando plena expressão aos interesses de cada região, o que refletia no plano

\footnotetext{
2 As pesquisas recentes sobre a escola primária, mais especificamente sobre os grupos escolares, evidenciam a importância deste modelo de estabelecimento para a construção física e ideológica em diferentes estados brasileiros, como por exemplo, São Paulo, Belo Horizonte, Curitiba, Santa Catarina, Sergipe em que temos trabalhos de referência nesta área, entre eles, podemos citar, Souza (1998, 2009), Faria Filho (2000; 2015), Peres (2000), Bencostta (2005) Buffa e Pinto (2002), Gonçalves (2004), Vidal (2006), Teive (2009a, 2009b), Silva e Teive (2009), Azevedo (2010), Sá e Sá (2011). A obra comparativa sobre a escola primária (1870-1930) organizada recentemente, contribui para uma análise entre 15 estados brasileiros (SOUZA; SILVA; SÁ, 2013). Dissertações e teses de diversas localidades do Brasil têm contribuído para o enriquecimento do tema, como por exemplo, em Natal/RN (MOREIRA, 2005); Santos/SP (BRASIL, 2008); Mococa/SP (PORCEL, 2007); Itapetininga/SP (STELLA, 2006).

3 O Decreto legislativo incorporado à constituição do Império, Ato Adicional de 1834, determinava a autonomia relativa das províncias, atribuindo às Assembleias Provinciais legislar sobre a instrução pública e estabelecimentos próprios a promovê-la (art.10, inciso 2). Desse modo, a instrução primária gratuita tornase dever das províncias (SUCUPIRA, 1996).
} 
político, com a formação de partidos republicanos restritos a cada estado, onde tentativas de organização de grupos nacionais não obtiveram sucesso (FAUSTO, 2001).

Sob liderança do Partido Republicano Rio-Grandense (PRR) ${ }^{4}$ e com forte centralização política, a Instrução Pública no Estado do Rio Grande do Sul estava submetida à Secretaria de Negócios do Interior, a cargo da Diretoria de Instrução Pública e seu Diretor. Dentre outras atribuições, era importante diagnosticar os problemas educacionais, com base em levantamentos e dados estatísticos, por meio dos quais foi constatado que o analfabetismo atingia a grande maioria da população. No Rio Grande do Sul, assim como ocorria em outros Estados, foram constantes os levantamentos numéricos das categorias de sexo, lugar e data de nascimento, profissão, estado civil. Ainda, da população que sabia ler e escrever, entre homens/mulheres e crianças ( 0 - 14 anos) e acima de 15 anos $^{5}$.

Nesse contexto, os relatórios anuais da Diretoria de Instrução Pública registravam além de dados quantitativos, a discursividade em torno da educação. Acompanhavam gráficos, mapas, plantas, projetos e fotografias, que se constituíram uma fonte privilegiada para historiadores da educação. Desse modo, o encontro com esse conjunto de fotografias deu-se durante a pesquisa nos Relatórios de Instrução Pública sobre os primeiros edifícios escolares construídos no Estado do Rio Grande do Sul, entre 18891930. Com um número de imagens bastante significativo para princípios do século XX, o anexo publicado em 1924, engloba 20 imagens, de 12 instituições de ensino de sete municípios do Estado. Produzidas pelo Governo do Estado do Rio Grande do Sul, registram o momento em que algumas das primeiras construções de edifícios escolares já estavam finalizadas. Apesar do edifício escolar se manter como principal protagonista (sendo o mesmo construído ou adaptado), temos a presença de outros sujeitos do universo escolar, como os/as alunos/as, professoras e a figura de um novo membro, o diretor.

Para fins de organização, as fotografias foram distribuídas a partir de quatro categorias de análise: edifícios e sujeitos escolares, nove (9); somente dos edifícios

\footnotetext{
${ }^{4}$ Foi a partir do Partido Republicano Rio-Grandense, criado em 1882, que se propôs a solução dos problemas do Estado através de um projeto de modernização, justificado a partir do conjunto de ideias elaboradas por Auguste Comte, vislumbrada na construção de uma sociedade racional, distinta da anterior.

${ }^{5}$ Sobre, ver Gomes (2002).
} 
escolares, seis (6); sala de aula e sujeitos, três (3); atividades escolares ao ar livre, duas (2). Os edifícios, estudantes e professores, assim como as atividades desenvolvidas, representam fragmentos da cultura escolar, captados pela lente fotográfica e possíveis de serem interpretados pelos pesquisadores.

Quadro 1: Instituições e municípios (1924)

\begin{tabular}{|l|l|l|}
\hline Número & \multicolumn{1}{|c|}{ Nome da instituição } & \multicolumn{1}{c|}{ Município } \\
\hline 1 & Escola Isolada & Porto Alegre \\
\hline 2 & Colégio Elementar Souza Lobo & Porto Alegre \\
\hline 3 & Colégio Elementar Fernando Gomes & Porto Alegre \\
\hline 4 & Colégio Elementar Voluntários da Pátria & Porto Alegre \\
\hline 5 & Escola Complementar (curso elementar anexo) & Porto Alegre \\
\hline 6 & Colégio Elementar de Bagé & Bagé \\
\hline 7 & Colégio Elementar de Santa Maria & Santa Maria \\
\hline 8 & Colégio Elementar de Montenegro & Montenegro \\
\hline 9 & Colégio Elementar de Cachoeira & Cachoeira \\
\hline 10 & Colégio Elementar de Santana do Livramento & $\begin{array}{l}\text { Santana do } \\
\text { Livramento }\end{array}$ \\
\hline 11 & Grupo Escolar de Estrela & Estrela \\
\hline 12 & Colégio Elementar de São Gabriel & São Gabriel \\
\hline
\end{tabular}

Fonte: elaborado pela autora, 2015.

As fotografias são compreendidas neste estudo como representações pictóricas do passado, com base na perspectiva de presentificação, que descreve algo de maneira indireta (RICOUER, 2007). Desse modo, consideramos o lapso de tempo entre o passado, que não se desloca e, o presente, que consiste em uma percepção da imagem através de um esforço subjetivo de rememoração. $O$ ato de lembrar e os suportes que estão envolvidos, como as fotografias, cartões postais, agendas, recibos e lembretes, consistem em uma espécie de proteção contra o esquecimento. O conjunto analisado representa um lócus privilegiado de memória histórico-educativa, especialmente em um contexto em que esse tipo de registro não era abundante. Conforme veremos a seguir, a construção visual da escola pública foi realizada a partir dos espaços e arquitetura escolar, sujeitos e da cultura material. 


\section{Fotografias, espaços e arquitetura escolar}

A difusão da imagem é de grande importância para a Primeira República no Brasil (1889-1930), um período em que a maioria da população, mesmo nos grandes centros urbanos, era analfabeta. A escola tornou-se entre as instituições visuais, como por exemplo, a empresa, o museu, o cinema e a comunicação de massa, um espaço de produção e circulação de imagens, especialmente a fotografia, no século XX. Nessa perspectiva, destacamos a capacidade da imagem em atingir todas as camadas sociais, sobreviver ao tempo e ultrapassar as diversas fronteiras sociais pelo alcance do sentido humano da visão (KNAUSS, 2006, p. 99).

A expansão da escola republicana se desenvolveu, em grande parte, pelos símbolos e imagens produzidos pelos dirigentes políticos. Ao lado de minuciosos relatórios anuais organizados pelas Secretarias de Instrução Pública/RS e Obras Públicas/RS, as fotografias serviam como uma espécie de comprovação daquilo que estava sendo produzido, ou seja, a difusão da educação pública primária traduzida pelo combate ao analfabetismo. Além dos relatórios oficiais, as escolas também fazem parte dos álbuns comemorativos do Estado, uma forma de publicitar, mesmo que entre uma minoria intelectualizada, a imagem da escola que estava sendo construída.

As fotografias dos prédios escolares, projetados ou adaptados para serem escolas, são compreendidas neste estudo além do seu caráter ilustrativo, mas como indícios de uma concepção de cultura, espaço e arquitetura escolar. Ao analisarmos o poder simbólico das imagens, observarmos que os "significados não são tomados como dados, mas como construção cultural”. Neste sentido, se compreendem as “disputas simbólicas como disputas sociais, sendo que o poder se realiza e se conserva pela produção de imagens e pela manipulação de símbolos" (BALANDIER, 1982 apud KNAUSS, 2006, p. 100).

O contexto da cidade de Porto Alegre, capital do Estado do Rio Grande do Sul, foi analisado por Possamai (2009a, 2009b), trabalhando aspectos da arquitetura escolar como parte da construção visual das instituições educativas, no cenário urbano. A partir da análise de fotografias, os levantamentos procedidos pela autora têm mostrado a 
importância dos edifícios escolares nos projetos de construção da escola pública, nas primeiras décadas do século XX.

A utilização das fontes iconográficas foi compreendida a partir dos estudos da cultura visual, o que significa que as mesmas não servem apenas para ilustrar ou complementar o texto, mas representam vestígios, sentidos e significados que as constituem como próprio texto. Assim como os discursos, que reportam uma imagem mental, as imagens reportam a uma mensagem discursiva.

Pozo e Rabazas (2012), ao analisarem as imagens fotográficas como fontes para estudo da cultura escolar, problematizam a importância atribuída às fotografias, propondo a reflexão acerca das informações significativas e exclusivas que somente esse tipo de fonte poderia oferecer. Destacam o uso corrente da triangulação de métodos e dados a fim de manter a validez contextual e de conteúdo das representações visuais entre os pesquisadores. Pela perspectiva dos estudos da cultura escolar, devemos atentar para as informações desconhecidas que as fotografias podem proporcionar, as práticas educativas cotidianas, o dia a dia em aula e outros aspectos difíceis de conhecer através de outros documentos.

A valorização da materialidade escolar tem possibilitado compreender que os espaços escolares, além de seus aspectos funcionais, incorporam uma série de elementos simbólicos. Desse modo, também cabe aos espaços escolares a tarefa de socializar e educar, constituindo um campo de forças materiais e sociais que articula sua configuração entre o aberto e o fechado, o interno e externo, o que é comum e aquilo que é designado a uma pessoa ou grupo específico (VIÑAO, 1998).

Nosso olhar para as fotografias enfatiza os espaços e a arquitetura escolar, compreendida por si mesma como um programa, uma espécie de discurso que institui em sua materialidade um sistema de valores, como os de ordem, disciplina e racionalidade, um dos marcos para a aprendizagem sensorial e motora e toda a semiologia que cobre diferentes símbolos estáticos, culturais e também ideológicos (ESCOLANO, 2000, p. 183). Apesar de um elemento extremamente visível, implícito ou manifesto, a arquitetura constitui-se em uma forma oculta, invisível e silenciosa de inculcar, transmitir, produzir e reproduzir valores, formas de ser aluno, criança e futuro cidadão. 
A importância visual dos prédios na concepção de uma educação de qualidade vinha sendo reproduzida nos discursos políticos logo após ser instituído o sistema político republicano ${ }^{6}$. Segundo Bencostta (2005), a proclamação da República ocorre diante de uma quase inexistente rede escolar no país, sendo que o analfabetismo atingia a maioria da população ${ }^{7}$. Neste contexto, a instrução pública deveria constituir uma das colunas de sustentação e consolidação do novo regime. Vislumbrada no imaginário republicano como instituição responsável pelo progresso nacional, a escola deveria ao mesmo tempo alfabetizar e inculcar valores morais para a formação do cidadão.

Fazia-se necessário, então, projetar e construir prédios escolares para a configuração de um espaço escolar adequado às novas propostas políticas e educacionais, e torná-los visíveis dentro do plano urbano das cidades, sendo uma arquitetura ornamentada e, em muitos casos, monumental (BUFFA e PINTO, 2002). Os espaços e os sujeitos são considerados nesta pesquisa enquanto fragmentos de memória, que capturados pelas lentes fotográficas adquirem, a partir dos olhares dos historiadores, incontáveis formas de interpretações e significados. Conforme nos coloca Grosvenor (2014, p. 31), "las fotografias tienen un carácter fluido. A pesar de que sus propriedades no cambian, a través de su existencia material acumulan distintos significados mientras entran en relación con nuevos contextos y públicos". Sua sobrevivência ao longo do tempo consiste em um importante elemento da memória individual e coletiva, que além da materialidade em si, evoca sentimentos e emoções, lembranças e rememorações ${ }^{8}$.

\footnotetext{
${ }^{6}$ Os projetos e construções de edifícios escolares tendem a, de um modo geral, acompanhar padrões arquitetônicos de âmbito internacional. Experiências europeias e norte-americanas são significativas para pensarmos as influências discursivas e materiais dos projetos e construções. Entretanto, são inúmeras as particularidades de cada edifício, seja em relação aos aspectos organizativos e funcionais, sejam os elementos simbólicos e ornamentais. Para uma análise mais aprofundada, ver Chatêlet (2006).

${ }^{7}$ A estatística educacional, organizada a partir do regime republicano pela Diretoria Geral de Estatística, criada ainda no Império, em 1871, apesar de não possuir dados confiáveis, produziu impactos diferenciados sobre o conhecimento e o planejamento do sistema educacional. A publicação da Estatística da Instrução, em 1916, traz os dados relativos aos 20 estados do país e do distrito federal, nos anos de 1907 e 1908. Com diferenças significativas quanto ao número de escolas, de professores e a matrícula escolar entre os estados, o quadro geral da instrução pública primária mostra que: para uma população de mil crianças brasileiras, apenas 137 estavam matriculadas e, dessas, apenas 96 frequentavam a escola, em 1908 (GOMES, 2002).

${ }^{8}$ Sobre, ver Grimaldi (2016).
} 


\section{Os edifícios, sujeitos e atividades escolares}

Analisamos o corpus documental destacando as principais características presentes nas fotografias escolares, no ano de 1924. Além disso, consideramos que o conjunto exerce o papel de auxiliar ou servidor da memória, testemunhando o acontecido e demonstrando que a fotografia pode servir como instrumento de transposição, de análise, de interpretação e de transformação. Como um registro do passado, que atravessa o tempo, pertence ao universo dos vestígios. De acordo com Mauad (2005, p. 139) a partir da noção de série/coleção, compreende-se a necessidade de não circunscrever a análise crítica sobre um único exemplar, necessitando, portanto, da formação de um conjunto de imagens em uma série.

Para compreendermos o contexto da produção dessas fotografias e do desenvolvimento da educação primária no Estado, cabe destacar a sua organização a partir das seguintes instituições: escola complementar, colégios elementares, grupos escolares, escolas isoladas, escolas subvencionadas pelo Estado, escolas municipais, escolas federais e escolas particulares ${ }^{9}$. Em 1921, o Governo do Estado declara o capital imobiliário do Estado do Rio Grande do Sul, sendo que 13 colégios elementares estavam funcionando em prédios de propriedade do Estado, 16 em prédios alugados e 5 em prédios de propriedade dos municípios. Referente aos grupos escolares, 4 funcionavam em prédios alugados e 5 em prédios municipais.

Em 1923, Protásio Alves ${ }^{10}$, político e Secretario dos Negócios do Interior e Exterior do Estado do Rio Grande do Sul, referendando à questão da instrução pública, salienta a necessidade de escolas - edifícios próprios para colégios - em todas as regiões,

\footnotetext{
${ }^{9}$ Cabe esclarecer que a organização da escola primária no Estado do Rio Grande do Sul se desenvolve de forma distinta dos outros Estados Brasileiros. As instituições de ensino primário modelares estavam organizadas a partir dos colégios elementares, sendo estes divididos conforme o quantitativo de frequência: de terceira entrância eram aqueles com mais de 400 alunos, deveriam ter 8 professores; os de segunda entrância, com mais de 300 alunos, com seis professores; e os de primeira entrância, entre 200 e 300 alunos, com 5 professores. Caso a instituição possuísse uma frequência inferior a 200 alunos era rebaixado de entrância e passava a denominar-se Grupo Escolar. Estes podiam funcionar conjuntamente, num só prédio sob denominação de grupo escolar, com três ou mais professores (CORSETTI, 1998, p. 310).

${ }^{10}$ Protásio Alves (1859-1933) estudou Medicina no Rio de Janeiro, viajou pela Europa e retornou ao Estado do Rio Grande Sul, onde iniciou sua carreira como médico e político, membro do Partido Republicano RioGrandense. Primeiramente, como Diretor da Higiene (1891-1896; 1901-1904), e, posteriormente, como Secretario dos Negócios do Interior e Exterior, cargo exercido entre 1906 e 1928, sob governo de Borges de Medeiros.
} 
principalmente na zona rural. Ainda, aponta que o Estado se empenha em desenvolver a instrução em seus mais distintos níveis, para que a população não precisasse sair para buscar qualificação profissional (Relatório de Instrução Pública do Estado do Rio Grande do Sul, 1923).

Havia uma preocupação crescente em propagar a instrução para diferentes localidades, na construção de prédios e melhoria nas condições gerais da educação. Grande parte da população escolar frequentava aulas isoladas de um professor, muitos sem formação para o exercício do magistério, que funcionavam em espaços adaptados e abandonavam as aulas logo após receber as primeiras noções de leitura e escrita. A frequência das aulas era irregular e a fiscalização, apesar de ser fortemente incentiva pelo Estado, não contemplava os espaços necessários.

Em relatório de 1924, a situação numérica do Estado quanto à instrução primária pública era a seguinte: 43 colégios elementares (de $1^{\mathrm{a}}, 2^{\mathrm{a}}$ e $3^{\mathrm{a}}$ entrâncias), 20 grupos escolares e uma escola complementar, em Porto Alegre, que formava professores para a instrução primária e possuía uma aula elementar anexa (escola experimental para aulas práticas das professoras em formação).

A primeira categoria de análise compreende um conjunto de nove (9) fotografias que trazem além do prédio, a presença de outros sujeitos do universo escolar professores/as, diretor e alunos/as em diferentes atividades. Ainda, outros sujeitos, que provavelmente são autoridades municipais, pais e/ou moradores da região.

O Colégio Elementar de Bagé está representado com um número significativo de quatro fotografias, sendo todas registradas na fachada do prédio, com uma visualização parcial do edifício. Uma imagem traz um grupo de escoteiros, em exercício de ginástica; duas, muito semelhantes, retratam, primeiro, um grupo de meninos, em uma, e de meninas na outra, em exercício de ginástica com a professora ao centro. Por fim, uma imagem traz a junção dos gêneros na mesma fotografia, mas em grupos separados, ficando novamente a professora ao centro, segurando uma bandeira. Tanto os meninos como as meninas estão uniformizados e posam, de forma distinta, em frente ao prédio, que aparece parcialmente, conforme um exemplo abaixo: 
Figura 1: Colégio Elementar de Bagé. Exercício de ginástica.

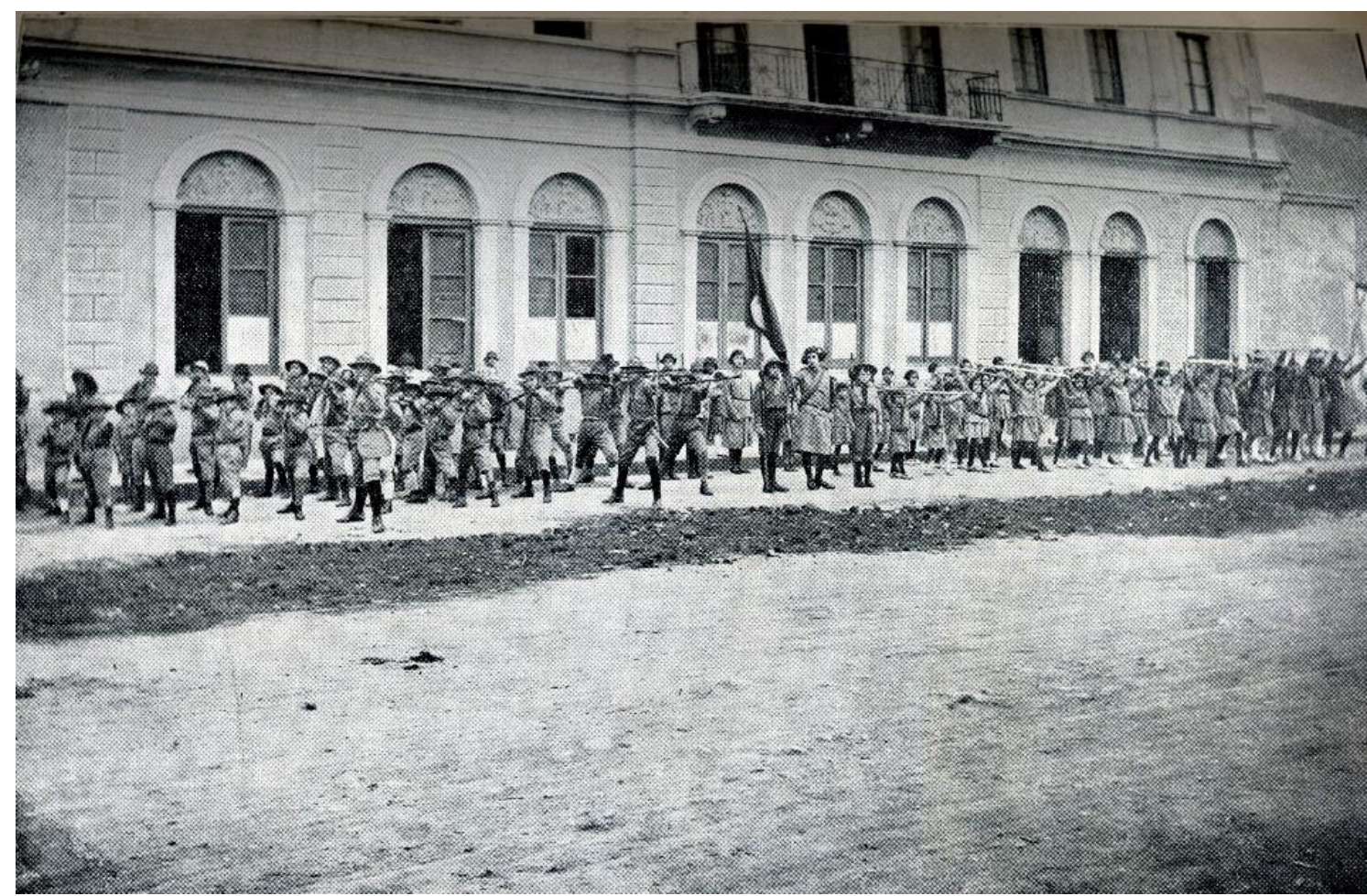

Fonte: Relatório de Instrução Pública do Estado do Rio Grande do Sul (1924, s/p).

Conforme a figura 1, podemos visualizar que os meninos se posicionam em forma de combate militar e as meninas erguem acima da cabeça uma espécie de bastão. A presença da professora, centralizada e com a bandeira faz-se presente em três das imagens. A formação física consistia em um dos pilares dos princípios de uma educação integral (física, moral e intelectual), sendo sua prática distinta para meninos e meninas, conforme é possível observar pela separação total dos grupos, assim como posicionamento e demais objetos utilizados pelos/as alunos/as.

Outras três fotografias de instituições distintas registram o momento de saída dos alunos, com a presença de professoras, do diretor e de outros membros da sociedade, tendo o edifício escolar ao fundo. Cabe destacar que a figura do diretor representa uma nova organização e hierarquia escolar. Segundo Peres (2010), os primeiros diretores dos colégios elementares "foram escolhidos entre os inspetores escolares, em uma clara manifestação do esforço para qualificar esses estabelecimentos” (p. 68). Nesse sentido, o cargo de diretor consistia em uma função de grande importância, tendo em vista que os 
inspetores escolares eram representantes do Diretor da Instrução Pública, ou seja, a presença do Governo do Estado nas escolas.

No Colégio Elementar de Santa Maria, na fotografia que registra o momento da saída de alunos do turno da manhã, o fotógrafo se posiciona mais distante, alcançando toda a dimensão do prédio e os alunos enfileirados. Notamos a ênfase no grandioso edifício, a presença de alunos de maneira ordenada, a figura de destaque de um homem vestido de preto, uma mulher e outro homem, que acompanham a fila, provavelmente professores. Em relação ao Colégio Elementar Voluntários da Pátria, de Porto Alegre, o mesmo momento é capturado com uma postura mais informal, em que os alunos estão descendo a escadaria principal e caminhando na parte frontal do edifício, na companhia de duas professoras e, uma outra em meio aos alunos na parte superior do prédio. Na varanda temos novamente a figura masculina de destaque, o diretor, conforme figura 2:

Figura 2: Colégio Elementar Voluntários da Pátria - Capital.

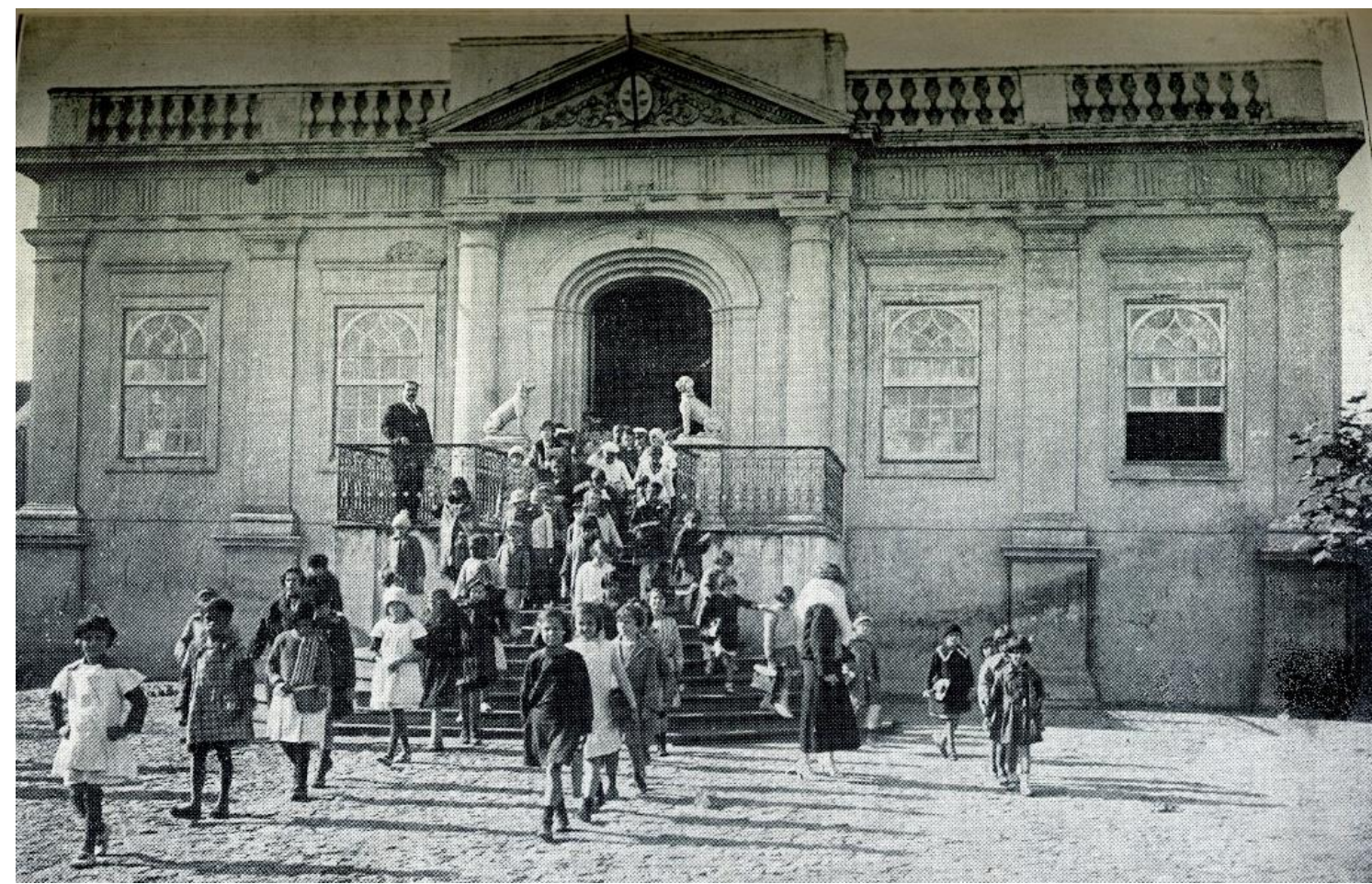

Fonte: Relatório de Instrução Pública do Estado do Rio Grande do Sul (1924, s/p).

Neste caso, visualizamos que mesmo sendo um registro não posado, é interessante destacar a separação por gênero, em que as meninas aparecem em primeiro plano, saindo na frente e, os meninos, mais distantes, ainda na porta e na escadaria da 
escola. A imagem abrange toda a dimensão do prédio, que foi adaptado de uma antiga residência de recepção de imigrantes para ser uma escola. As primeiras meninas que saem e se deparam com o fotógrafo apresentam uma postura mais estática, quase posada, demostrando o estranhamento da presença de um sujeito externo no espaço escolar. Outro aspecto relevante que conseguimos observar é a presença de uma menina negra em um universo de estudantes de cor branca.

Seguindo a mesma perspectiva das saídas dos estudantes, a Escola Complementar da Capital foi registrada a partir de um ângulo lateral, com a presença de alguns alunos em frente ao prédio (figura 3 ) $^{11}$. Posicionado em uma esquina, o mesmo servia para a formação do magistério e possuía uma escola elementar anexa, para realização de práticas das professoras em formação. Além da presença das professoras, temos meninos de diferentes idades em pontos distintos da rua.

Figura 3: Escola Complementar - Capital.

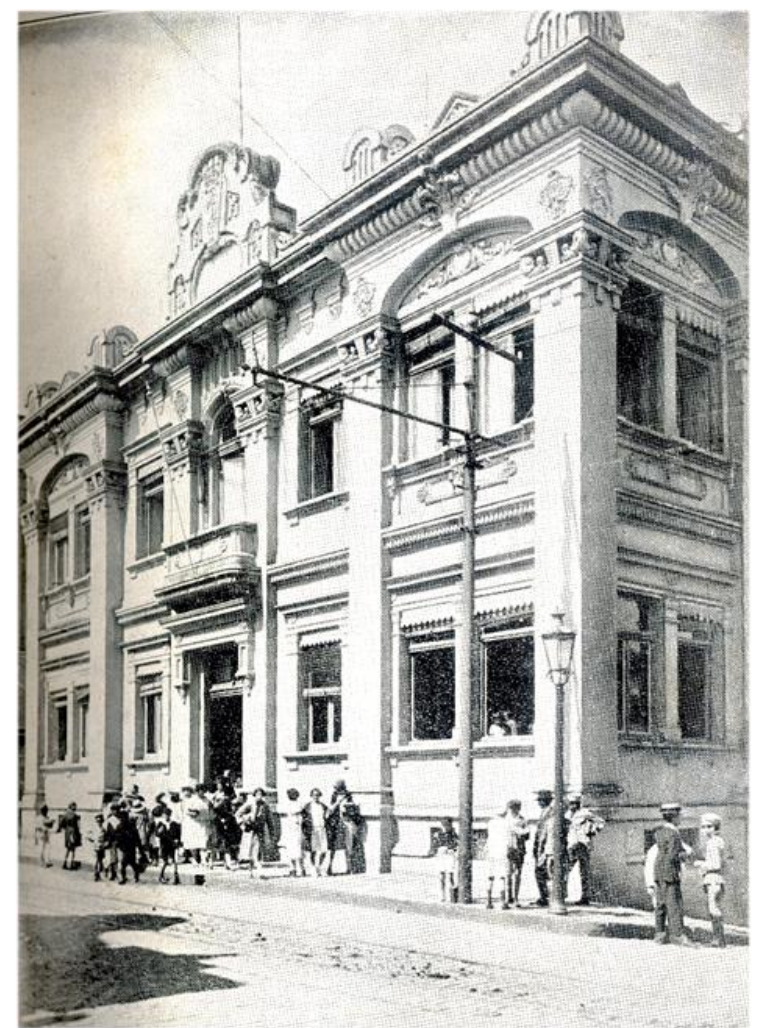

Fonte: Relatório de Instrução Pública do Estado do Rio Grande do Sul (1924, s/p)

\footnotetext{
${ }^{11}$ A Escola Normal de Porto Alegre passou por diferentes momentos e nomenclaturas: Escola Normal (18691901); Colégio Distrital (1901-1906); Escola Complementar (1906-1929); Escola Normal (1929-1935); Escola Normal General Flores da Cunha (1935-1937). Entre 1939 e 2006, foi denominada Instituto de Educação General Flores da Cunha. A partir de 2006, recebe o nome: Centro Estadual de Formação de Professores General Flores da Cunha, localizado na Avenida Osvaldo Aranha, 527. Sobre, ver Porto (2013).
} 
Podemos analisar nesses três registros do momento da saída dos estudantes Colégio Elementar Voluntários da Pátria, Colégio Elementar de Santa Maria e Escola Complementar da Capital - que os edifícios aparecem em sua totalidade, merecendo destaque a supervisão do diretor e das/as professores/as em relação aos alunos/as. Nem todas as crianças possuem uniforme escolar, o que pode ser um vestígio do processo de heterogeneidade da escola pública primária em princípios do século XX.

No Colégio Elementar “14 de Julho”, do município de Montenegro, as alunas estão uniformizadas em exercício de ginástica, em primeiro plano e, o prédio distante, com a bandeira nacional centralizada (figura 4 ).

Figura 4: Colégio Elementar "14 de Julho", de Montenegro. Grupo de alunas em exercício de ginástica.

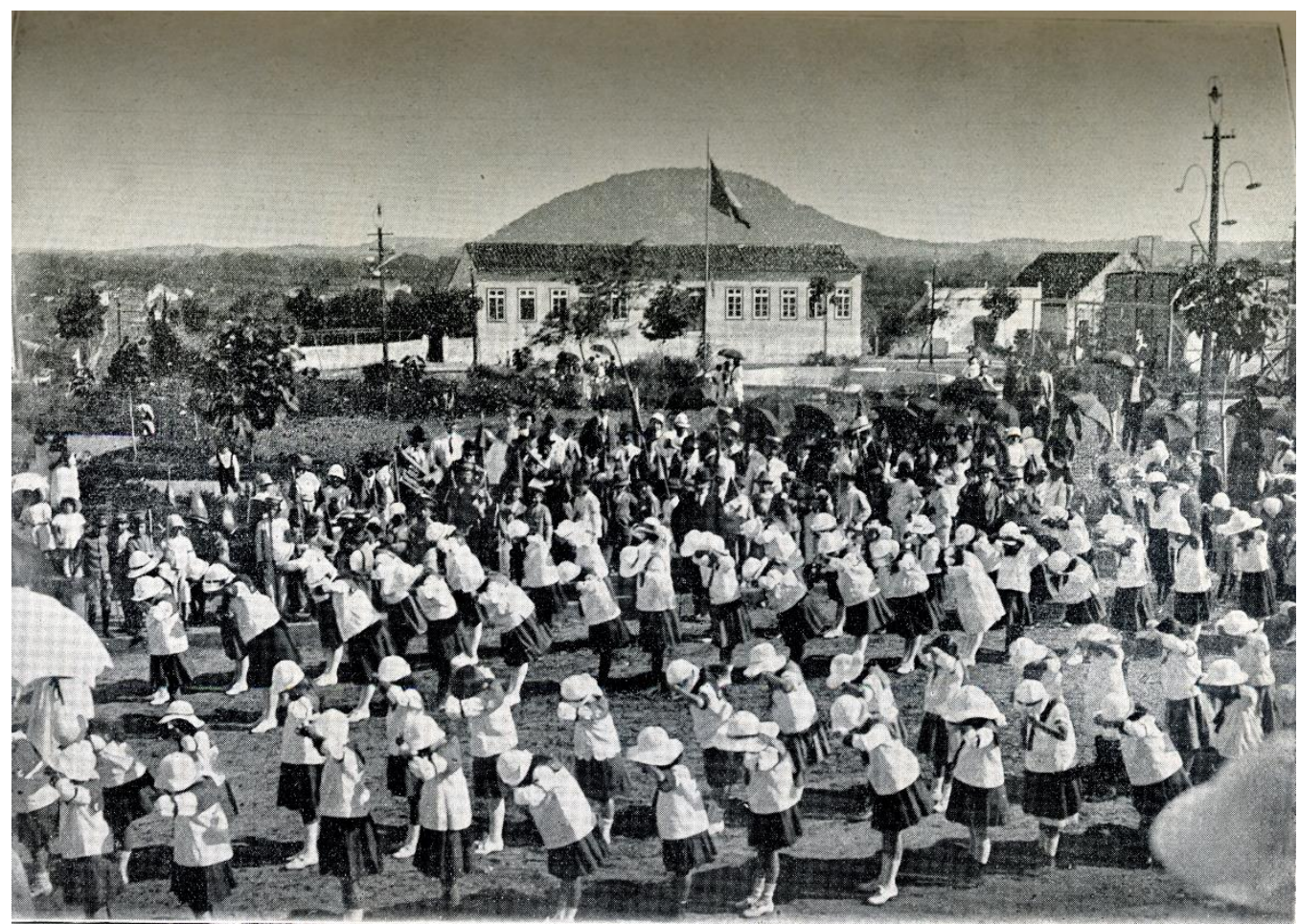

Fonte: Relatório de Instrução Pública do Estado do Rio Grande do Sul (1924, s/p).

Conforme visualizamos na imagem, o edifício, de proporção menos monumental, fica distante da lente do fotógrafo, que aproveita a luz e foca em primeiro plano as alunas vestidas de branco, com a presença de algumas sombrinhas nas laterais, também de cor branca. Em um plano mais distante, estão os meninos, provavelmente o diretor e algumas 
pessoas com sombrinhas escuras. O número e a dispersão de pessoas nos indicam a possibilidade da presença de autoridades municipais e moradores da região.

Outro registro é realizado no Grupo Escolar de Estrela, com uma posição posada na escadaria principal da escola, com a presença de alunos/as que dividem o mesmo espaço da imagem. Em planos distintos, temos em frente 50 meninos uniformizados e com chapéus, a maioria sentada, organizados de acordo com o tamanho. Visualizamos dentro dessa homogeneidade marcada pela construção da imagem, a presença de dois meninos negros lado a lado na segunda fileira e outro sozinho na última fileira. Ainda, temos três meninos brancos sem chapéu, na última fileira, de modo que ficassem pouco visíveis. Misturados aos grupos de meninas, com uniforme branco, seguindo a mesma cor do uniforme das meninas e sem chapéu, temos ainda quatro meninos menores, sendo um negro. As meninas, 33 no total, estão posando em pé atrás dos meninos, merecendo destaque o uniforme e os laços que a maioria traz no cabelo. O prédio escolar é representado a partir do fragmento da escadaria, parte da porta e janelas, conforme a figura a seguir.

Figura 5: Grupo de Estrela - Setembro de 1920.

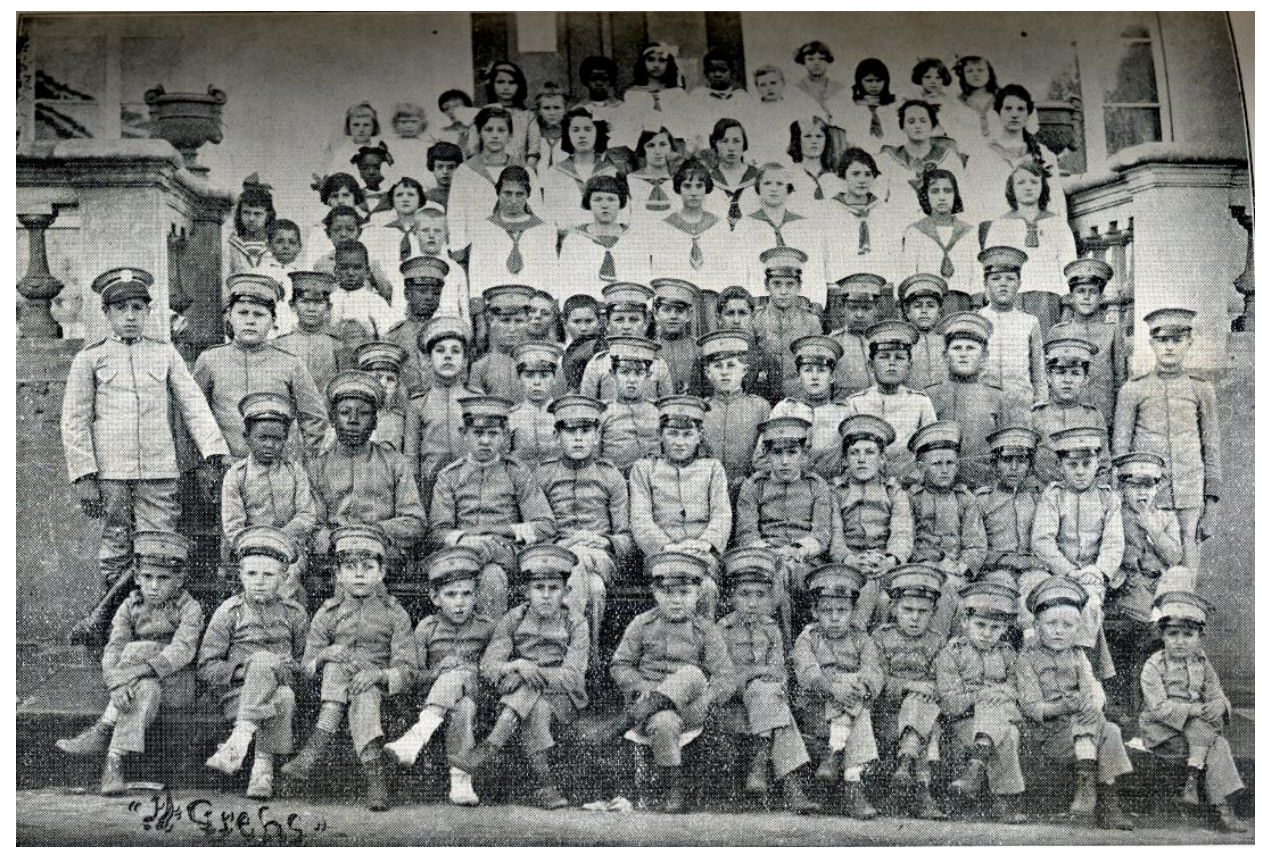

Fonte: Relatório de Instrução Pública do Estado do Rio Grande do Sul (1924, s/p).

Podemos observar neste primeiro conjunto a constituição da memória escolar relativa aos espaços e os sujeitos escolares, sendo representados em um princípio de 
homogeneidade, a partir da presença do edifício, do diretor, dos/as professor/as e alunos/as. Por outro lado, também é possível assinalar as particularidades, como os distintos ângulos, a posição da luz, o ordenamento dos corpos e as atividades desenvolvidas, representando as distintas formas de constituição da imagem da escola primária nas cidades do Estado. Devemos considerar a intencionalidade do Governo estadual em construir um "retrato" de escola primária, a partir de uma conjuntura que ainda estava separada por gênero, em edifícios adaptados, sendo composto por um corpo discente fragmentado e com pouca frequência, convivendo com a falta de inspeção escolar e com as deficiências na formação do magistério. Ainda, partilhando com outras realidades nacionais e internacionais, o desafio de implementar o ensino seriado e a expansão da alfabetização, que consistiam na resolução problemas que estavam distantes de serem resolvidos.

O segundo grupo de maior representação numérica, com (6) fotografias, registra apenas o prédio escolar, trazendo, de modo geral, a fachada principal, a partir de um ângulo que se possa visualizar a extensão lateral do prédio. Neste conjunto, temos a presença da Escola Isolada de Porto Alegre, prédio próprio do Estado, construído em 1907 a partir do projeto-tipo de escolas de 1899; o Colégio Elementar Fernando Gomes, prédio construído entre 1913-1922 na Rua Duque de Caxias, em Porto Alegre, com proporções monumentais; o Colégio Elementar Souza Lobo, prédio adaptado em 1913 para o funcionamento das aulas no bairro São Geraldo/Porto Alegre e ampliado em 1916; o Colégio Elementar de São Gabriel, prédio construído pelo município, no início do século XX; o Colégio Elementar de Livramento, prédio construído pelo Estado, em 1917; e Escola Complementar de Porto Alegre (curso elementar anexo), prédio construído entre 1919 e 1922.

A análise da discursividade dos dirigentes republicanos em torno das construções escolares possibilita descrever a crítica direcionada à estrutura das aulas que funcionavam em casas alugadas, assim como a valorização da construção dos projetos para os prédios escolares. O Governo do Estado, durante o período da Primeira República, concretizou alguns poucos casos de prédios escolares, sendo que a grande maioria das aulas continuou funcionando em espaços adaptados, seja através do aluguel ou da compra de casas residenciais (ERMEL, 2017). 
O Colégio Elementar Fernando Gomes ${ }^{12}$, construído em proporções monumentais na cidade Porto Alegre, ocupa um quarteirão, com 92 aberturas (figura 6). Um dos elementos mais significativos é o pórtico de entrada, constituído por duas gigantescas colunas com mais de treze metros de altura, uma escadaria que dá acesso à porta principal, duas estátuas em ferro bronzeado e ainda um mosaico composto por figuras femininas, livros, globo, lira e as inscrições “ciências” e "artes” (ERMEL, 2011).

Figura 6: Colégio Elementar Fernando Gomes - Capital.

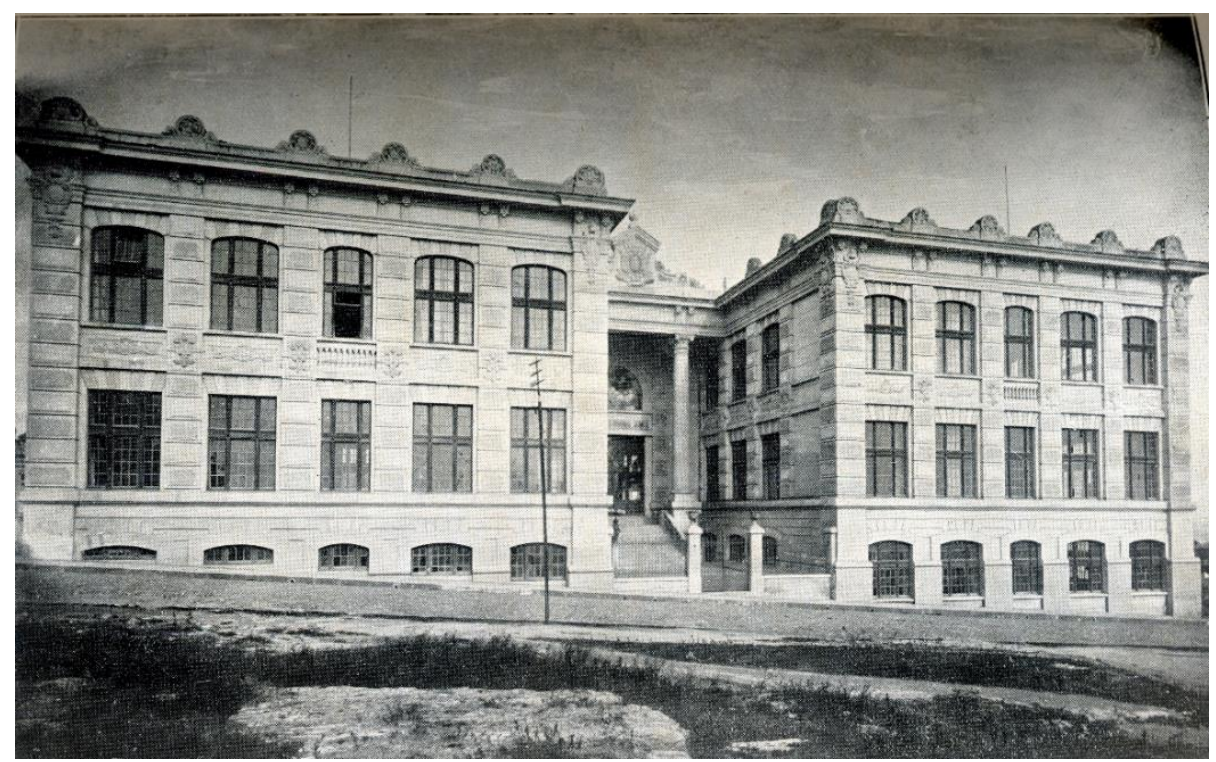

Fonte: Relatório de Instrução Pública do Estado do Rio Grande do Sul (1924, s/p).

Outro exemplo, também da cidade de Porto Alegre, consiste em um prédio escolar adaptado de uma antiga fábrica, na Rua Bahia, zona norte da cidade (figura número 7). Denominado Colégio Elementar Souza Lobo, estava composto por quatro construções idênticas, passando por inúmeras reformas a partir de 1918. O conjunto de prédios foi demolido, em 1962, e a escola recebeu uma construção.

\footnotetext{
${ }^{12}$ No ano de 1946, o Colégio Elementar Fernando Gomes, neste momento denominado Grupo Escolar Fernando Gomes, é transferido para o Grupo Escolar Paula Soares, localizado na Rua General Auto, anexo ao Palácio do Governo, centro de Porto Alegre. Neste mesmo ano, começa a funcionar no prédio a primeira escola técnica feminina da Capital, recebendo a denominação de Escola Técnica Senador Ernesto Dornelles. Continua funcionando atualmente neste mesmo local, oferecendo cursos para ambos os sexos.
} 
Figura 7: Colégio Elementar Souza Lobo - Capital (zona sub-urbana).

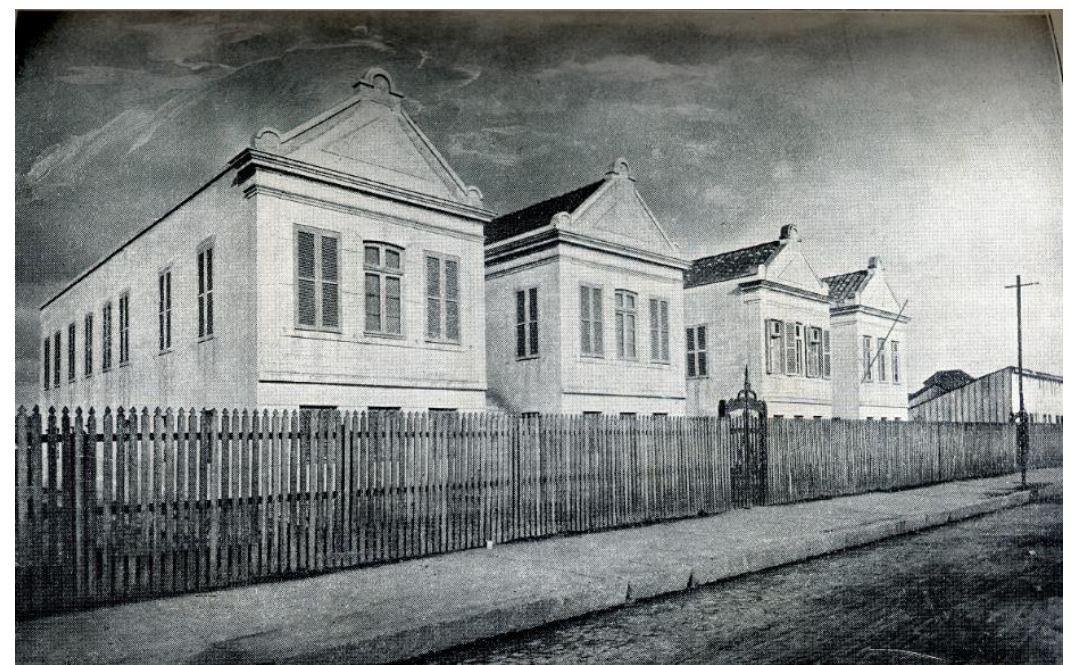

Fonte: Relatório de Instrução Pública do Estado do Rio Grande do Sul (1924, s/p).

Analisando os registros dos edifícios escolares, podemos observar que a prioridade do Governo do Estado foi de registrar aqueles construídos com a finalidade de serem escolas, sendo ainda recorrente a atenção destinada às estruturas monumentais. De acordo com Ermel (2011), a maioria das instituições de ensino primárias no Estado do Rio Grande do Sul, durante a Primeira República Brasileira (1889-1930), seguiram suas atividades em espaços adaptados, onde não estavam alinhadas às prescrições econômicas, já que os aluguéis aumentavam significativamente; pedagógicas, pois não comportavam o número de alunos e não os dividia em graus de adiantamento, conforme recomendava a pedagogia moderna e; higiênicas, em salas pequenas, com pouca entrada de ar e luz, e sem sanitários.

Outro aspecto que podemos assinalar são as diferentes dimensões e linguagens arquitetônicas, tendo em vista os tipos de escolas primárias existentes no Estado. A “Aula Isolada Campo da Redenção", de Porto Alegre, por exemplo, apresentava dimensões reduzidas, onde estava previsto o trabalho de uma professora, que ministraria aula em apenas duas salas, com capacidade total de 60 alunos e sem sanitários no interior do edifício (figura 8). O piso inferior poderia servir de espaço para recreio em dias de chuva ou de moradia para a professora (Relatório da Instrução Pública, 1907). Sua fachada era ornamentada, mas simples, sendo que a construção foi finalizada em pouco mais de um ano. Já o Colégio Elementar Fernando Gomes, construído também em Porto Alegre, entre 
1913 e 1922, era composto por três pavimentos, várias salas de aula, sala de direção, fachada e pórtico de entrada ricamente ornamentados, com materiais importados em estilo neoclássico e com sanitários em todos os andares. Estava preparado para receber diferentes níveis de ensino e um número total de mais de mil alunos.

Figura 8: Capital - Aula Isolada - Tipo de Construção (1924).

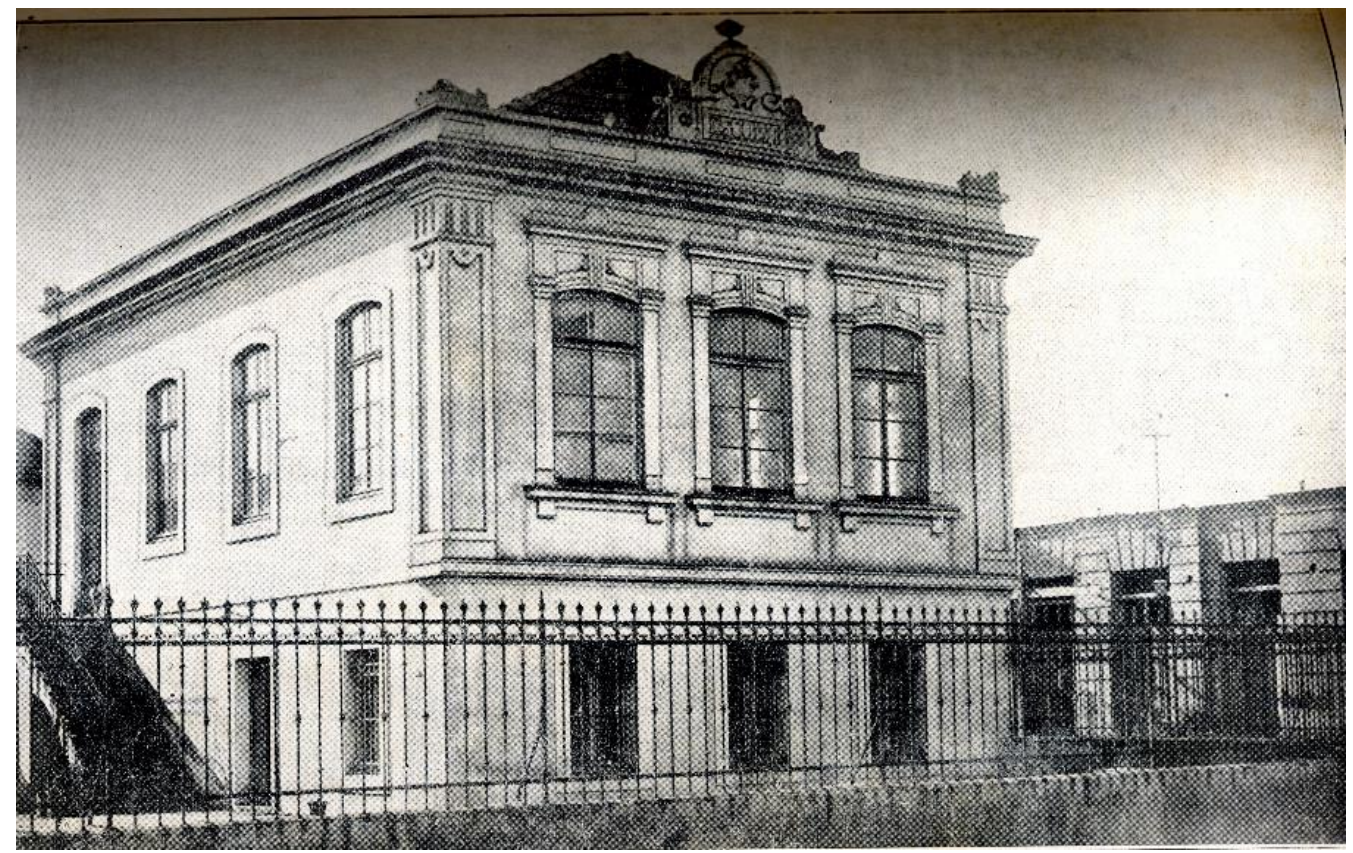

Fonte: Relatório de Instrução Pública do Estado do Rio Grande do Sul (1924, s/p).

Os registros do interior dos espaços escolares consistem em três fotografias de salas de aula, sendo duas do curso elementar da Escola Complementar de Porto Alegre e, outra, de uma aula de música do Colégio Elementar de Cachoeira. Do Curso Elementar Anexo de Porto Alegre, temos uma sala de aula onde as alunas de uniforme branco estão sentadas com uma das mãos erguidas e duas professoras em pé. Outra, de uma aula prática de formação do magistério da mesma instituição, as alunas do curso elementar estão sentadas e as alunas do curso de formação do magistério estão em pé, na parte frontal da sala de aula, fazendo anotações na presença de professoras. O ponto central dessa última fotografia consiste no registro da prática das alunas-mestras em formação e não as alunas do curso elementar, que estão de costas, conforme figura a seguir. 
Figura 9: Escola Complementar Capital - Aula de Prática (1924).



Fonte: Relatório de Instrução Pública do Estado do Rio Grande do Sul (1924, s/p).

Em outro registro desta categoria, de uma aula de música do Colégio Elementar de Cachoeira, temos a presença alunos de ambos os sexos e de duas professoras. A sala de aula está bastante ornamentada com cartazes e as professoras em frente, ao lado do quadro negro, em posição de ensino, uma com a mão erguida e outra apontado para a matéria no quadro, conforme figura número 10.

Figura 10: Colégio Elementar de Cachoeira - grupo de alunas em aula de música (1924).

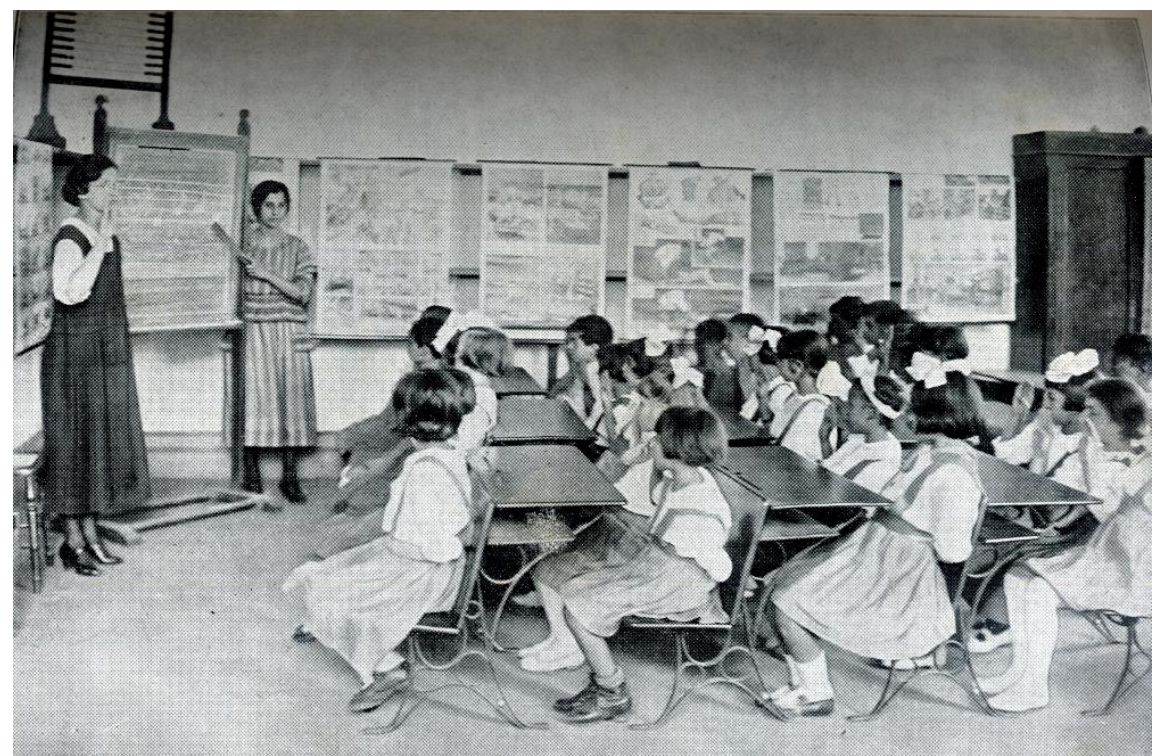

Fonte: Relatório de Instrução Pública do Estado do Rio Grande do Sul (1924, s/p). 
Conforme podemos observar, o foco principal dos registros no interior dos edifícios escolares consistia em momentos de formação de professoras e das atividades em sala de aula, com amplo material exposto, como é possível visualizar na aula de Música no município de Cachoeira. O mobiliário, uniforme, armário e material de ensino adequado era uma realidade bastante distante da maioria das escolas primárias, conforme relatos do próprio governo do Estado. A Escola Complementar da Capital deveria servir de modelo, sendo que muitas professoras vinham do interior para realizar seus estudos e retornavam para as suas cidades, a fim de aplicar os conhecimentos aprendidos. O curso Elementar Anexo, que teve seu prédio concluído em 1922, consistia em uma espécie de laboratório de formação para as alunas-mestras. Desse modo, as fotografias podem ser indagadas enquanto elementos da memória de um espaço físico e ideológico de prestígio educacional, que representavam a formação de uma elite do magistério rio-grandense.

A seguir, temos duas fotografias de estudantes ao ar livre, ambas do Colégio Elementar de Santa Maria, sendo que uma consiste no registro do Grupo General Osório, em atividade militar na presença do instrutor e, outra, de um grupo de alunas em exercício de ginástica. Na primeira, os alunos estão enfileirados, uniformizados e em posição militar, com três alunos em destaque, à frente, sendo que um deles porta a bandeira nacional. $\mathrm{O}$ instrutor aparece ao lado esquerdo e, a paisagem consiste em um campo com construções distantes, conforme figura a seguir:

Figura 11: Colégio Elementar em Santa Maria - Companhia General Osório e seu instrutor (1924).

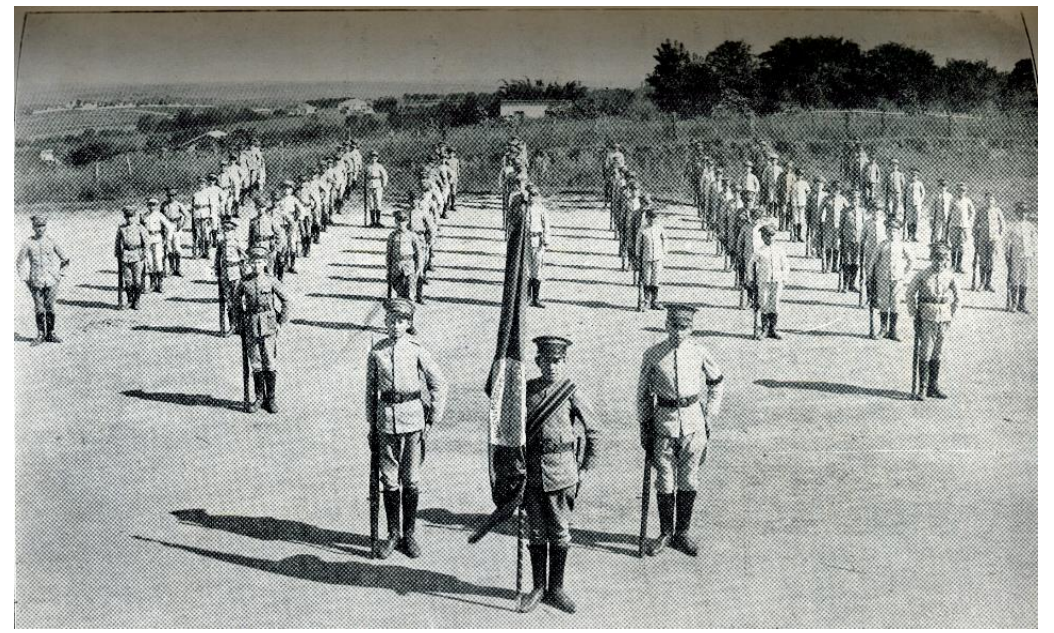

Fonte: Relatório de Instrução Pública do Estado do Rio Grande do Sul (1924, s/p). 
$\mathrm{Na}$ imagem das alunas em exercício de ginástica, também enfileiradas e uniformizadas, as mesmas estão cercadas pela vegetação e algumas construções distantes, conforme figura 12:

Figura 12: Colégio Elementar em Santa Maria - Grupo de meninas em exercício de ginástica



Fonte: Anexo do Relatório de Instrução Pública do Estado do Rio Grande do Sul (1924).

Nas fotografias analisadas, tanto ao ar livre como no interior das escolas (ver figuras 9, 10, 11 e 12), podemos identificar o registro dessas distintas atividades, como por exemplo, as alunas-mestras desenvolvendo suas aprendizagens no curso elementar, a aula de música, em uma sala de aula ornamentada com vários cartazes e, especialmente as aulas de ginástica, para ambos os sexos. De acordo com o ideal de uma educação que regenerasse a sociedade, desde final do século XIX estava prevista uma série de conhecimentos que almejavam ir além do ensino da leitura, escrita e cálculos. Visava uma formação do magistério e uma educação integral primária, desde o ponto de vista moral, físico e intelectual. O curso primário compreenderia o ensino de português, geografia e história pátria, noções de geografia e história geral, aritmética e geometria práticas, contabilidade, noções de escrituração mercantil e agricultura, lições de coisas, trabalhos manuais, desenho a mão livre, elementos de música vocal, ginástica sueca e evoluções militares nas escolas do sexo masculino. 
O conjunto ao qual damos visibilidade neste estudo representa aspectos de uma cultura escolar que sobreviveu no transcurso do tempo e que integra um importante elemento da memória da educação. Nelas, observamos traços de uma escola primária pública através de seus espaços, do corpo docente e discente, de seus diretores e demais autoridades públicas que estavam implicadas nesta conjuntura.

\section{Considerações finais}

O estudo remonta a um período histórico no qual a construção de uma rede de instrução pública estava em pauta em diferentes estados brasileiros. Almejando o aumento do número de crianças alfabetizadas, a escola deveria ser o espaço de formação do cidadão republicano, sendo que o passado colonial e imperial deveria ficar para trás rumo ao progresso de uma nova sociedade. Desse modo, além dos relatórios escritos que demandavam os levantamentos qualitativos e quantitativos da educação, os registros fotográficos constituíram uma importante forma de divulgar a ação em torno da escola pública, envolvendo tanto os espaços internos e externos, como os sujeitos que faziam parte dessa nova configuração, ou seja, os professores de diferentes níveis, diretores e alunos de ambos os sexos.

Conforme assinalamos anteriormente, as fotografias foram analisadas com base na perspectiva da presentificação, considerando os seus inúmeros sentidos e significados, que fazem parte da memória escolar. Sendo assim, esse conjunto incorpora o papel de evocador ou auxiliar da memória, repleto de aspectos que podem remeter sobre a homogeneidade e particularidades em relação ao ensino primário público no Estado do Rio Grande do Sul. Consiste em uma documentação oficial, que a partir de diferentes ângulos, cidades e instituições representa uma escola voltada para a construção de um espaço escolar. Constatamos a presença total ou parcial do edifício escolar na maioria dos registros, com ou sem os sujeitos envolvidos no processo educativo. Essa recorrência nos permite refletir acerca da importância dos espaços e, mais particularmente, da arquitetura escolar, no momento da organização de um sistema de ensino que visava atender as necessidades funcionais e incorporar elementos simbólicos da República Brasileira. 
De acordo com Peres (2010), a implementação dos colégios elementares significou um novo modelo escolar no estado e a reinvenção de uma cultura escolar primária. A estatização da escolarização, a obrigatoriedade e expansão do ensino, os grupos homogêneos e classes graduadas, o agrupamento de vários professores em um único espaço, o controle do tempo, o surgimento da figura do diretor, o estabelecimento de um programa de ensino, a construção do edifício escolar, entre outras estratégias, foram desenvolvidas pelo Estado com a intenção de deixar o passado marcado pelo atraso e seguir um futuro rumo ao progresso, a partir da formação da infância.

Podemos constatar, a partir do conjunto de fotografias analisadas, que a maioria dos edifícios está situada na capital do Estado, sendo prioridade registrá-los na presença dos alunos. Nesse sentido, o espaço e o corpo discente constituem o foco principal, merecendo destaque as fotografias posadas de atividades físicas e militares. Ainda, assinalamos a presença de diferentes tipos de instituições primárias, sendo os colégios elementares o modelo de instrução. Destacamos a presença dos prédios construídos, com predomínio para o registro das construções monumentais. Tampouco podemos deixar de salientar que, em menor número, temos um grupo escolar e uma aula isolada, assim como registro de prédios adaptados.

As fotografias escolares compreendem, muito além de um corpus material, uma possibilidade de adentrar no universo da cultura escolar de diferentes tempos e espaços, sendo um elemento evocador da memória histórico-educativa. Conforme a citação de Ricouer (2007) ao início deste estudo, o conjunto fotográfico analisado nos convida a exercitar a imaginação em torno da gênese da escola primária no Rio Grande do Sul, sendo que alguns prédios, já demolidos, apenas são possíveis de serem estudados a partir desses registros. Outros, conservados ao longo do tempo, necessitam ser problematizados através de sua história, memória e patrimônio, merecendo destaque suas transformações e permanências ao longo do tempo.

Outros aspectos merecem ser aprofundados, tais como: discentes separados por gênero, mesmo que ocupando um lugar comum; o uso de uniformes; a militarização da infância; as atividades físicas e específicas (como aula de música ou aula de prática) fotografias posadas e espontâneas; a supervisão de adultos (professores, diretores e instrutores); a presença de alunos/as afrodescendentes, dentre outras inúmeras 
possibilidades de interpretação que os diferentes olhares podem construir valendo-se do uso das fotografias.

\section{Referências}

AZEVEDO, Crislaine Barbosa de. Grupos escolares em Sergipe - 1911-1930: cultura escolar, civilização e escolarização da infância. Natal: Editora da EDUFRN, 2010.

BALANDIER, Georges. O poder em cena. Brasília: Ed. UnB, 1982.

BENCOSTTA, Marcus Levy; BRAGA, Marina Fernandes. História e arquitetura escolar: a experiência dos regulamentos franceses e brasileiros para os edifícios escolares (18901910). Revista Linhas. Florianópolis, v. 12, n. 01, p. 51-72, jan./jun., 2011. Disponível em: <http://www.revistas.udesc.br/index.php/linhas/article/view/2275>.

BENCOSTTA, Marcus Levy Albino (Org.). Arquitetura e espaço escolar: o exemplo dos primeiros grupos escolares de Curitiba (1903-1928). In: BENCOSTTA, Marcus Levy Albino (Org.). História da educação, arquitetura e espaço escolar. São Paulo: Cortez, 2005.

BENCOSTTA, Marcus Levy; MEIRA, Antonia de. Fotografias e culturas escolares: universo digital e preservação da memória. In: Anais do III Congresso Brasileiro de História da Educação. A Educação Escolar em Perspectiva Histórica. Curitiba: SBHE, Pontifícia Universidade Católica do Paraná, 2004. Disponível em: <http://www.sbhe.org.br/novo/congressos/cbhe3/Documentos/Individ/Eixo1/169.pdf >. Acesso em 14 de julho de 2014.

BRASIL, Márcio. O Grupo Escolar Visconde de São Leopoldo e a escolarização de Vila Macuco durante a Primeira República. Dissertação. (Mestrado em Educação). Universidade Católica de Santos. São Paulo, 2008.

BUFFA, Ester; PINTO Gelson de Almeida. Arquitetura e educação: organização do espaço e propostas pedagógicas dos grupos escolares paulistas, 1893-1971. São Carlos: Brasília: EdUFSCar, INEP, 2002. 
CHÂTELET, Anne-Marie. Ensaio de Historiografia I: a arquitetura das escolas no Século XX. Tradução Marcus Levy Albino Bencostta. Revista História da Educação, ASPHE/FaE/UFPel, Pelotas, n. 20, p. 7-38, set., 2006.

CORSETTI, Berenice. Controle e ufanismo: a escola pública no Rio Grande do Sul (18901930). 1998. Tese (Doutorado em Educação) - UFSM, Santa Maria, 1998.

ERMEL, Tatiane de Freitas. O gigante do alto da bronze: um estudo sobre o espaço e arquitetura escolar do Colégio Elementar Fernando Gomes em Porto Alegre/RS (19131930). 2011. Dissertação (Mestrado em Educação) - PUCRS, Faculdade de Educação, 2011. ERMEL, Tatiane de Freitas. Arquitetura escolar e Patrimônio histórico-educativo: os edifícios para a escola primária pública no Rio Grande do Sul (1907-1928). Tese (Doutorado em Educação) - PUCRS, Porto Alegre, 2017.

ESCOLANO, Agustín Benito. Tiempos y espacios para la escuela: ensaios históricos. Madrid: Biblioteca Nueva, 2000.

FARIA FILHO, Luciano Mendes. Dos pardieiros aos palácios: cultura escolar e urbana em Belo Horizonte na Primeira República. Passo Fundo/RS: UPF, 2000.

FARIA FILHO, Luciano Mendes. Dos pardieiros aos palácios: forma e cultura escolar em Belo Horizonte (1906/1918). $2^{\text {a }}$ ed. Uberlândia: Editora da Universidade Federal de Uberlândia, 2015.

FAUSTO, Boris. História concisa do Brasil. São Paulo: Editora da Universidade de São Paulo: Imprensa Oficial do Estado, 2001.

GOMES, Ângela de Castro. A república no Brasil. Rio de Janeiro: Nova Fronteira, 2002. GONÇALVES, Irlen. Antonio. Cultura Escolar, práticas e produção dos grupos escolares em Minas Gerais (1891-1918). Tese (Doutorado em Educação) - Universidade Federal de Minas Gerais, Faculdade de Educação, 2004.

GRIMALDI, Lucas. Na sensibilidade da memória estudantil: prédios e espaços escolares nas narrativas de estudantes em Porto Alegre/RS (1920-1980). Dissertação (Mestrado em Educação) - UFRGS, Faculdade de Educação, Programa de Pós-Graduação em Educação. Porto Alegre, 2016.

GROSVENOR, Ian. El professorado y la escuela renovadora: vida de una profesora en imágenes. In: COLLELLDEMONT, Eulàlia (Org.). Investigar la historia de l'educació amb imatges. eumogràfic - MUVIP: Vic/Barcelona, 2014. p. 21-34.

KNAUSS, Paulo. O desafio de fazer história com imagens: arte e cultura visual. ArtCultura, v. 8, n. 12, p. 97-115, 2006.

MAUAD, Ana Maria. Na mira do olhar: um exercício de análise da fotografia nas revistas ilustradas cariocas, na primeira metade do século XX. Anais do Museu Paulista, São Paulo, v. 1, n. 1, p. 133-174, 2005. 
MOREIRA, Ana Zélia Maria. Um espaço pioneiro de modernidade educacional: Grupo Escolar Augusto Severo - Natal/RN - 1908-13. 2005. Dissertação (Mestrado em Arquitetura e Urbanismo) - Universidade Federal do Rio Grande do Norte, 2005.

PERES, Eliane T. Aprendendo formas de pensar, de sentir e de agir: a escola como oficina da vida - discursos pedagógicos e práticas escolares da escola pública gaúcha (19091959). 2000. Tese (Doutorado em Educação) - Universidade Federal de Minas Gerais, Belo Horizonte 2000.

PERES, Eliane. A escola graduada no Rio Grande do Sul no início do século XX: a implantação de um novo modelo e de uma nova cultura escolar. In: VIDAL, Diana Gonçalves; SCHWATZ, Cleonara Maria (org.). História das culturas escolares no Brasil. Vitória: EDUFES. Coleção Horizontes da pesquisa em História da Educação no Brasil, vol.1, 2010, p. 59-92.

PORCEL, Najar Roberto. República e Educação: as imagens arquitetônicas e jornalísticas do Grupo Escolar “Barão de Monte Santo" (Mococa-SP). 2007. Dissertação (Mestrado em Educação) - Universidade Estadual de Campinas, Faculdade de Educação. Campinas, 2007.

\section{GONÇALVES, Dilza Porto Gonçalves. A instrução pública, a educação da mulher e a} formação de professores nos jornais partidários de Porto Alegre/RS (1869-1937). Tese (Doutorado em História). Programa de Pós-Graduação em História/PUCRS, Porto Alegre, 2013.

POSSAMAI, Zita. A cultura fotográfica e a escola desejada: considerações sobre imagens de edificações escolares - Porto Alegre (1919 - 1940). In: Anais Encontro nacional de estudos da imagem, Londrina, 12 a 14 de maio de 2009a, p. 930-948.

POSSAMAI, Zita. Uma escola a ser vista: apontamentos sobre imagens fotográficas de Porto Alegre nas primeiras décadas do século XX. História da Educação, ASPHE/FaE/UFPel, Pelotas, v. 13, n. 29, p.143-169, set./dez., 2009b.

POZO, Maria del Mar Andrés; RABAZAS, Teresa Romero. Las imágenes fotográficas como fuente para el estudio de la cultura escolar: precisiones conceptuales y metodológicas. Revista Ciencias de la Educación, n. 231-232, p. 401-414, dez., 2012.

Relatório da Diretoria de Instrução Pública do Estado do Rio Grande do Sul, 1907. Officinas Graphicas d' A Federação, Porto Alegre, vol.1, 1907.

Relatório apresentado ao Exmo. Sr. Dr. A. A. Borges de Medeiros, presidente do Estado do Rio Grande do Sul, pelo Dr. Protásio Alves (Secretário de Estado dos negócios do interior e exterior), em 04 de setembro de 1921. Officinas Graphicas d' A Federação, Porto Alegre, vol. 1, 1922.

Relatório apresentado ao Exmo. Sr. Dr. A. A. Borges de Medeiros, presidente do Estado do Rio Grande do Sul, pelo Dr. Protásio Alves (Secretário de Estado dos negócios do interior e exterior), em 31 de agosto de 1923. Officinas Graphicas d' A Federação, Porto Alegre, vol. 1, 1923. 
Relatório apresentado ao Exmo. Sr. Dr. A. A. Borges de Medeiros, presidente do Estado do Rio Grande do Sul, pelo Dr. Protásio Alves (Secretário de Estado dos negócios do interior e exterior), em 31 de agosto de 1923. Officinas Graphicas d' A Federação, Porto Alegre, vol. 2, 1923.

Relatório apresentado ao Exmo. Sr. Dr. A. A. Borges de Medeiros, presidente do Estado do Rio Grande do Sul, pelo Dr. Protásio Alves (Secretário de Estado dos negócios do interior e exterior), em 06 de setembro de 1924. Officinas Graphicas d' A Federação, Porto Alegre, vol. 1, 1924.

RICOEUR, Paul. A memória, a história, o esquecimento. Tradução: Alain François et al. Campinas, SP: Editora da UNICAMP, 2007.

SÁ, Nicanor Palhares; SÁ, Elizabeth Figueiredo de (Orgs.). Revisitando a história da escola primária: os grupos escolares em Mato Grosso na Primeira República Brasileira. Cuiabá: Ed. UFMT, 2011.

SILVA, Vera Lucia Gaspar da; TEIVE, Gladys Mary Ghizoni. Grupos Escolares: criação mais feliz da República? Mapeamento da produção em Santa Catarina. Revista Linhas, Florianópolis, v. 10, n. 1, p. 31-53, jan./jun., 2009.

SOUZA, Rosa Fátima de; SILVA, Vera Lúcia Gaspar da; SÁ, Elizabeth Figueiredo de. (Orgs.). Por uma teoria e uma história da escola primária no Brasil: investigações comparadas sobre a escola graduada (1870-1930). Cuiabá: EdUFMT, 2013.

SOUZA, Rosa Fátima de. Tempos de Civilização: a implantação da Escola Primária Graduada no Estado de São Paulo (1890-1910). São Paulo: Ed. UNESP, 1998.

SOUZA, Rosa Fátima de. Alicerces da pátria: história da escola primária no Estado de São Paulo (1890-1976). Campinas, SP: Mercado das Letras, 2009.

STELLA, Paulo Rogério. Ordem? qual ordem? a circulação de valores em um arquivo de correspondências de um Grupo Escolar (1905-1911). 2006. Tese (Doutorado em Lingüística Aplicada e Estudos de Linguagem) - Pontifícia Universidade Católica de São Paulo, São Paulo, 2006.

SUCUPIRA, Newton. O Ato Adicional de 1834 e a descentralização da Educação. In: FÁVERO, Osmar (Org.). A Educação nas constituintes brasileiras 1823-1988. Campinas: Editora Autores associados, 1996 p. 55-68.

TEIVE, Gladys Mary Ghizoni. Grupo escolar e produção do sujeito moderno: um estudo sobre o currículo e a cultura escolar dos primeiros grupos escolares catarinenses (19111935). História da Educação (UFPel), v. 13, p. 57-78, $2009 a$.

TEIVE, Gladys Mary Ghizoni. Grupo escolar e governamentalidade liberal moderna: nova forma escolar, novos dispositivos, novas subjetividades. Série-Estudos (UCDB), v. 27, p. 209-222, 2009b. 
TRILLA, Jaume. Ensayos sobre la escuela: el espacio social y material de la escuela. Barcelona: Ediciones Laertes, 1999.

VIDAL, Diana G. (Org.). Grupos Escolares: cultura escolar primária e escolarização da infância no Brasil (1893 - 1971). Campinas, São Paulo. 2006.

VIÑAO, Antonio. Do espaço escolar e da escola como lugar: propostas e questões. In: VIÑAO, Antonio; AGUSTÍN Escolano. Currículo, espaço subjetividade: a arquitetura como programa. Trad. Alfredo Veiga Neto. Rio de Janeiro: DP\&A, 1998.

Recebido em: 26/08/2016 Correções requeridas em: 09/02/2017 Aprovado em: 09/03/2017

Universidade do Estado de Santa Catarina - UDESC Programa de Pós-Graduação em Educação - PPGE

Revista Linhas

Volume 19 - Número 40 - Ano 2018 revistalinhas@gmail.com 